\title{
ANALISIS PERPUTARAN MODAL KERJA TERHADAP EFEKTIVITAS PENERIMAAN KAS PADA KOLOMPOK USAHA BERSAMA MAWAR MERAH DI BALIASE KABUPATEN LUWU UTARA
}

\author{
Samsul Bachri ${ }^{1}$ \\ Milda $^{2}$
}

No. HP $08124228783^{1}$

\begin{abstract}
ABSTRAK
Tujuan penelitian untuk mengetahui efektivitas perputaran modal kerja terhadap penerimaan kas pada kolompok usaha bersama mawar merah dibaliase.Adapun metode analisis yang digunakan yaitu metode analisis kuantitatif atau rasio aktivitas ialah perputaran kas yang hasilnya dari tahun 2010 sebesar 13,4 dan tahun 2011 sebesar 6,42 perputaran tersebut mengalami penurunan Karena penjualan tunai rata-rata kas yang diterimah lebih besar dibandingkan dengan bertambahnya penjualan tunai. perputaran persediaan pada KUB Mawar Merah dari tahun ke tahun peningkatan. Pada tahun 2010 perputaran persediaan sebesar 2,20 kali, tahun 2011 perputaran persediaan sebesar 2,88 kali .Perputaran persediaan mengalami peningkatan karena harga pokok penjualan dan rata-rata persediaan mengalami peningkatan. Sehingga dapat dikatakan meningkatnya perputaran persediaan menunjukan cepatnya penjualan, hal itu dapat diketahui bahwa perputaran persediaan sangat efektif.
\end{abstract}

Kata kunci : KUB mawar merah,Peningkatan Perputaran modal kerja

\section{PENDAHULUAN}

Pada dasarnya tujuan perusahaan didirikan adalah untuk mencapai keuntungan maksimal, menjaga kelangsungan hidup perusahaan dan mencapai kesejahteraan masyarakat sebagai tanggung jawab sosial perusahaan, disamping itu setiap perusahaan akan selalu mengembangkan atau memperluas usahanya. Untuk itu, maka bagi setiap perusahaan di dalam mengelola usahanya selalu membutuhkan modal kerja yang cukup. Kebutuhan modal kerja perlu diperhitungkan secara cermat dan tepat, sehingga perusahaan dapat mengalokasikan modal kerja secara baik dan tepat, dalam arti menggunakannya secara efektif dan efisien.

Adanya modal kerja yang cukup adalah sangat penting karena dengan modal kerja yang cukup dalam artian modal kerja yang tersedia sesuai dengan kapasitas usahanya, hal tersebut memungkinkan bagi perusahaan untuk beroperasi dengan se-ekonomis mungkin dan perusahaan tidak mengalami kesulitan dalam menghadapi bahaya-bahaya yang mungkin timbul karena adanya krisis atau kesulitan keuangan, akan tetapi dengan modal kerja yang berlebihan menunjukkan adanya dana yang tidak produktif dan hal tersebut akan menimbulkan kerugian bagi perusahaan karena adanya kesempatan untuk memperoleh keuntungan telah disiasiakan, sebaliknya adanya ketidak cukupan dalam modal kerja merupakan sebab utama kagagalan suatu perusahaan, oleh karena itu alat analisis perputaran kas, perputaran 
piutang, perputaran persediaan dan perputaran modal kerja merupakan suatu analisis yang menggambarkan seberapa besar kebutuhan modal kerja dan perubahan unsur-unsur modal kerja selama periode yang bersangkutan serta dapat mengetahui seberapa efektif modal kerja dalam perusahaan tersebut, dimana modal kerja merupakan dana yang harus tersedia dalam perusahaan yang dapat digunakan untuk menjalankan kegiatan operasinya sehari-hari.

Perputaran Kas, Riyanto (2001):

\section{METODE PENELITIAN}

Penelitian ini penulis laksanakan pada KUB Mawar Merah di Baliase Kabupaten Luwu Utara. Jenis data yang digunaka yaitu data kuantitatif dan data kualitatif. Sedangakan sumber data yang digunakan yaitu data primer dan data sekunder. Metode pengumpulan data tersiri dari pengamatan, wawancara dan dokumentasi.

\section{Metode Analisis Data}

Data-data yang diperoleh sedapat mungkin dianalisis secara kuantitatif, berikut ini teknik analisis yang dapat digunakan yaitu;

Perputaran Kas $=\frac{\text { Penjualan }}{\text { Rata-Rata Kas }} \times 1$ kali
Perputaran Piutang $=\frac{\text { Penjualan Kredit }}{\text { Rata-Rata Piutang }} \times 1$ kali

Perputaran Persediaan $\quad=\quad \frac{\mathrm{Hpp}}{\text { Rata-Rata Persediaan }} \times 1$ kali

365 hari

a. Periode pengumpulan kas $=$

Perputaran kas $\times 1$ hari

b. Periode pengumpulan piutang $=$

365 hari

Perputaran piutang

c. Periode pengumpulan persediaan $=\frac{365 \text { hari }}{\text { Perputaran persediaan }} \times 1$ hari 


\section{HASIL PENELITIAN}

\section{Perputaran Kas}

Perputaran Kas $\quad=\frac{\text { Penjualan }}{\text { Modal Kerja Bersih }} \times 1$ kali

Berikut ini disajikan data perputaran modal kerja KUB Mawar Merah pada tahun 20102011:

Perputaran Kas Tahun $2010=\frac{198.000 .000}{14.322 .000}$

$$
=13,8 \text { kali }
$$

Perputaran Kas Tahun $2011=\frac{235.200 .000}{36.600 .000}$

$$
=6,42 \text { kali }
$$

Tabel 1: Perputaran Persediaan Kolompok Usaha Bersama Mawar Merah Tahun 2010-2011

\begin{tabular}{|c|c|c|c|}
\hline Tahun & Penjualan & rata-rata kas & Perputaran Kas \\
\hline 2010 & $198,000,000$ & $14,322,000$ & 13.8 \\
\hline 2011 & $235,200,000$ & $36,600,000$ & 6.42 \\
\hline
\end{tabular}

Dari tabel di atas dapat diketahui bahwa dana yang tertanam dalam perputaran persediaan pada Kolompok Usaha Bersama Mawar Merah dari tahun ke tahun meningkat.

Pada tahun 2010 perputaran persediaan sebesar 2,20 kali, tahun 2011 perputaran persediaan sebesar 2,88 kali.

Karena harga pokok penjualan dan rata-rata persediaan mengalami peningkatan.
Sehingga dapat dikatakan meningkatnya perputaran persediaan menunjukan cepatnya penjualan, hal itu dapat diketahui bahwa perputaran persediaan sangat efektif.

\section{Periode Perputaran Modal Kerja}

\section{Periode Perputaran kas}

Periode perputaran kas $=\frac{365}{\text { Perputaran Kas }} \times 1$ hari Berikut ini disajikan data perputaran kas KUB Mawar Merah pada tahun 2010-2011;

Periode perputaran kas Tahun 2010

$=\frac{365}{13,8}=26,44$ hari

Periode perputaran kas Tahun 2011

$=\frac{365}{6,42}=52,85$ hari

Tabel 2: Periode Perputaran kas Kolompok Usaha Bersama Mawar Merah Tahun 2010-2011

\begin{tabular}{|c|c|c|c|}
\hline Tahun & Hari & $\begin{array}{c}\text { Modal Kerja } \\
\text { (dalam 1 kali) }\end{array}$ & Perputaran kas \\
\hline 2010 & 365 & 13.8 & 26.44 \\
\hline 2011 & 365 & 6.42 & 56.85 \\
\hline
\end{tabular}

Dari tabel diatas dapat dilihat perputaran kas Kolompok Usaha Bersama Mawar Merah pada tahun 2010 yaitu sebesar 26,44 hari.

Kemudian pada tahun 2011 meningkat menjadi 56,85. Hal ini dapat disimpulkan bahwa meningkat dan dapat dikatakan efisien karena hasil dari perputaran kas yaitu penjualan dibagi dengan rata-rata kas yang hasilnya akan dihitung dari periode 
perputaran kas yaitu 365 hari di bagi dengan perputaran kas tersebut .

Sehingga dapat disimpulkan bahwa periode perputaran kas yang dihitung perhari ternyata lebih besar dibandingkan perputaran kas dalam 1 tahun.

\section{Periode Perputaran Persediaan}

Periode Perputaran Persediaan

$$
=\frac{360}{\text { Perputaran Persediaan }} \times 1 \text { hari }
$$

Berikut ini disajikan data perputaran Persediaan KUB Mawar Merah pada Tahun 2010-2011:

Periode Perputaran Persediaan Tahun 2010 $=\frac{365}{2,20}=165,90$ hari

Periode Perputaran Persediaan Tahun 2011 $=\frac{365}{2,88}=126,73$ hari

Tabel 3: Periode Perputaran Persediaan Kolompok Usaha Bersama Mawar MerahTahun 2010-2011

\begin{tabular}{|c|c|c|c|}
\hline Tahun & Hari & $\begin{array}{c}\text { Perputaran } \\
\text { Persediaan }\end{array}$ & Persediaan \\
\hline 2010 & 365 & 1.61 & 165.9 \\
\hline 2011 & 365 & 1.69 & 126.73 \\
\hline
\end{tabular}

Dari tabel di atas dapat diketahui bahwa jangka waktu persediaan pada Kolompok Usaha Bersama Mawar Merah pada tahun 2010 selama 165,90 hari, tahun 2011 selama 126,73 hari. Waktu yang dibutuhkan dari tahun ke tahun mengalami penurunan tidak efisien.
Karena hasil dari perputaran persediaan yaitu harga pokok penjualan dibagi dengan rata-rata persediaan hasilnya akan dihitung dari 365 hari dibagi dengan hasil perputaran persediaan. Maka dapat disimpulkan bahwa periode perputaran persediaan yang dihitung dalam perhari lebih rendah dibandingkan dengan perputaran persediaan dalam 1 tahun.

Dari hasil perhitungan terlihat bahwa persediaan dari tahun ke tahun semakin sebentar mengendap di gudang.

1. Neraca Laporan Keuangan.

Neraca adalah laporan yang menggambarkan posisi keuangan perusahaan, terdiri dari Aktiva (harta kekayaaan), Kewajiban dan Modal pada suatu tanggal tertentu. Berikut adalah Neraca laporan keuangan Kolompok Usaha Bersama Mawar Merah pada tahun 2010 sampai tahun 2011;

\section{Tabel 4: Neraca Saldo (Trial Balance) Kolompok Usaha Bersama Mawar MerahPer 31 Desember}

\begin{tabular}{|l|c|c|}
\hline \multicolumn{1}{|c|}{ Aktiva } & 2010 & 2011 \\
\hline Kas & 14.322 .000 & 36.600 .000 \\
Piutang Dagang & 25.000 .000 & 34.152 .000 \\
Persediaan & 80.136 .000 & 73.125 .000 \\
\cline { 2 - 3 } Total Aktiva Lancar & $119,458,000$ & 143.877 .000 \\
& & \\
Total Aktiva Tetap & $10,128,000$ & 16.248 .000 \\
\hline Total Aktiva & $\mathbf{1 2 9 . 6 4 0 . 0 0 0}$ & $\mathbf{1 5 0 . 1 2 5 . 0 0 0}$ \\
\hline Passiva & 2010 & 2.011 \\
\hline \multirow{3}{*}{ Utang Usaha } & 12.128 .000 & 18.113 .000 \\
\hline Total utang usaha & 12.128 .000 & 18.113 .000 \\
\cline { 2 - 3 } & & 131.912 .000 \\
\hline Modal Usaha & 117.512 .000 & 130.125 .000 \\
\cline { 2 - 3 } Total Passiva & $\mathbf{1 2 9 . 6 4 0 . 0 0 0}$ & $\mathbf{1 5 0 0}$ \\
\hline
\end{tabular}


2. Laporan Laba Rugi

Laporan laba rugi adalah suatu laporan sistematis yang menggambarkan hasil operasi perusahaan dalam suatu periode waktu tertentu.

Hasil operasi perusahaan diperoleh dengan cara membandingkan antara penghasilan yang diperoleh dengan beban- beban yang telah dikeluarkan untuk memperoleh penghasilan tersebut. Berikut adalah Laporan laba-rugi Kolompok Usaha Bersama Mawar Merah dari tahun 2010 sampai tahun 2011 ;

Tabel 5: Laporan Laba Rugi

Kolompok Usaha Bersama Mawar Merah Untuk Tahun yang Berakhir 31 Desember

\begin{tabular}{|l|c|c|}
\hline Laporan Laba Rugi & 2010 & 2011 \\
\hline Penjualan & 198.000 .000 & 235.200 .000 \\
Hpp & 177.040 .000 & 211.000 .000 \\
\cline { 2 - 3 } Laba Kotor & $\mathbf{2 0 . 9 6 0 . 0 0 0}$ & $\mathbf{2 4 . 2 0 0 . 0 0 0}$ \\
\cline { 2 - 3 } & & \\
Beban Gaji & 5.000 .000 & 6.000 .000 \\
Beban Listrik dan Gas & 800.000 & 900.000 \\
\hline Penghasilan Pajak & 1.500 .000 & 2.000 .000 \\
\hline Jumlah Beban Usaha & 7.300 .000 & 8.900 .000 \\
\cline { 2 - 3 } Laba Bersi & $\mathbf{1 3 . 6 6 0 . 0 0 0}$ & $\mathbf{1 5 . 3 0 0 . 0 0 0}$ \\
\hline
\end{tabular}

3. Laporan Perubahan Modal Kerja

Istilah modal kerja digunakan dalam arti yang berbeda-beda. Pendekatan yang praktis adalah dengan memperkenalkan penggunaan istilah yang ditemui pada laporan tahunan perusahaan, dimana modal kerja didefinisikan sebagai aktiva lancar dikurangi kewajiban lancar. Modal kerja merupakan investasi perusahaan dalam bentuk uang tunai, surat berharga, piutang dan persediaan, dikurangi dengan kewajiban lancar yang digunakan untuk membiayai aktiva lancar.

Berikut ini adalah laporan perubahan modal kerja Kolompok Usaha Bersama Mawar Merah Pada tahun 20102011:

Tabel 6: Laporan Perubahan Modal Kerja Kolompok Usaha Bersama Mawar Merah Tahun 2010-2011

\begin{tabular}{|c|c|c|c|c|}
\hline \multirow[b]{2}{*}{ Keterangan } & \multicolumn{2}{|c|}{ 31-Dec } & \multicolumn{2}{|c|}{ Modal Kerja } \\
\hline & 2010 & 2011 & Naik & Turun \\
\hline Kas & $14,322,000$ & $36,600,000$ & $22,278,000$ & \\
\hline Piutang Dagang & $25,000,000$ & $34,152,000$ & $9,152,000$ & \\
\hline Persediaan & $80,136,000$ & $73,125,000$ & & $-7,011,000$ \\
\hline Total Aktiva Lancar & $119,458,000$ & $143,877,000$ & $24,419,000$ & \\
\hline Utang Usaha & $12,128,000$ & $18,113,000$ & $5,985,000$ & \\
\hline Total utang lancar & $12,128,000$ & $18,113,000$ & $5,985,000$ & \\
\hline Modal Kerja & $107,330,000$ & $125,764,000$ & $18,434,000$ & \\
\hline
\end{tabular}

Dari tabel di atas dapat diketahui bahwa pada tahun 2011 kas KUB Mawar Merah mengalami peningkatan sebesar Rp. $22,278,000$, piutang dagangnya mengalami peningkatan sebesar Rp. 9,152,000 dan persediaannya mengalami penurunan sebesar Rp 7,011,000.Sehingga total aktivanya mengalami peningkatan sebesar Rp. 24,419,000 Utang lancar KUB Mawar 
Merah pada tahun 2011 mengalami peningkatan sebesar Rp.5,985,000.

Sehingga setelah dikurangi dari total peningkatan aktiva tetap maka pada tahun 2011 terjadi peningkatan modal kerja pada KUB Mawar Merah yaitu sebesar Rp. 18,434,000. Peningakatan modal kerja ini dipengaruhi oleh faktor-faktor kunci yang telah mempengaruhi posisi keuangan KUB Mawar Merah.Faktor kunci tersebut adalah aktiva lancar dan hutang lancar.

Kondisi keuangan KUB Mawar Merah pada periode 2010-2011 baik aktiva lancar pada tahun 2010 adalah Rp.119,458,000 tahun 2011 Rp.143,877,000.

Sedangkan laba yang di peroleh tiap tahunnya juga mengalami ppeningkatan yakni tahun 2010 sebesar Rp. 13,660,000, tahun 2011 sebesar Rp.15,300,000.Hal ini menunjukkan bahwa kondisi keuangan pada KUB Mawar Merah tersebut LIKUID dan tingkat perputaran minimal modal kerja menyebabkan efisiensi pada "KUB Mawar Merah “.

\section{SIMPULAN}

Berdasarkan hasil analisis data pada bab IV, maka dapat ditarik kesimpulan:

1. perputaran modal kerja Kolompok Usaha Bersama Mawar Merah pada tahun 2010 yaitu sebesar 13,8 kali kemudian tahun 2011 menurun menjadi 6,42 kali.Perputaran kas mengalami penurunan karena penjualan tunai rata-rata kas yang diterimah lebih besar dibandingkan dengan bertambahnya penjualan tunai.

2. perputaran persediaan pada KUB Mawar Merah dari tahun ke tahun peningkatan. Pada tahun 2010 perputaran persediaan sebesar 2,20 kali, tahun 2011 perputaran persediaan sebesar 2,88 kali .Perputaran persediaan mengalami peningkatan karena harga pokok penjualan dan ratarata persediaan mengalami peningkatan. Sehingga dapat dikatakan meningkatnya perputaran persediaan menunjukan cepatnya penjualan, hal itu dapat diketahui bahwa perputaran persediaan sangat efektif.

3. Periode perputaran modal kerja :

a. perputaran modal kerja KUB Mawar Merah pada tahun 2010 yaitu sebesar 26,44 hari,kemudian pada tahun 2011 meningkat menjadi sebesar 56,85 .

b. jangka waktu persediaan pada KUB Mawar Merah pada tahun 2010 selama 1,65,90 hari, tahun 2011 selama 126,73 hari,Waktu yang dibutuhkan dari tahun ke tahun mengalami penurunan. Dari hasil perhitungan terlihat bahwa persediaan dari tahun ke tahun semakin sebentar mengendap di gudang.

\section{SARAN}

1. Sebaiknya Kolompok Usaha Bersama Mawar Merah dapat memanajemen rasio aktivitasnya dengan baik agar keuntungan yang didapatkan menjadi lebih besar. 
2. Sebaiknya Kolompok Usaha Bersama Mawar Merah selalu melakukan perhitungan terhadap rasio aktivitasnya agar dapat mengetahui tingkat kemampuan manajemen usahanya agar di tahun-tahun mendatang memperoleh keuntungan yang lebih besar.

\section{DAFTAR PUSTAKA}

Agus Sartono, 2001. "Manajemen Keuangan Teori dan Aplikasi” Yogyakarta: BPEFYOGYAKARTA.

Bambang Riyanto. 2001. "Dasar-Dasar Pembelanjaan Perusahaan" .Yogyakarta : BPFE-Yogyakarta.

Baridwan, Zaki, 2004." Akuntansi Aktiva Tetap" Yogyakarta:PT.Tokoh Gunung Agung.

Harahap, Syafri Sofyan, 2004. "Analisis Iritis Atas Laboran Keuangan" Cetakan Keempat, Yakarta : PT. Raja Grafindo Persada.

Kasmir. 2010." Pengantar Manajemen Keuangan dan Perputaran Modal Kerja”. Jakarta:Kencana.66

Lukman Syamsudin. 2000."Manajemen Keuangan Perusahaan". Jakarta.

Mulyadi.2007. "Sistem Akuntansi Penyusunan Prosedur”. ,Yogyakarta:PT.Alfabeta.

Munawir. 2007. "Analisis Laporan Keuangan”. Yogyakarta.

Ridwan S. Sundjaja dan Inge Barlian, 2002," Manajemen Keuangan Satu", Edisi. Keempat, Prenhallindo, Jakarta.

Riyanto. 2001:335. "Rasio aktivitas yang tinggi akan meningkatkan laba" :Jakarta.
S. Munawir. 2007. " Analisa Laporan Keuangan". Yogyakrta.

Siagian.1997 "Modal Kerja" :Jakarta

Stoner,Freeman Dan Gliber.1991."Efektivitas penerimaan Kas".yogyakarta.

Soehrto, Iman. (2001)." Manajemen Proyek Dari Konseptual Sampai Operasional". Jilid 2, Edisi ke-2. Erlangga, Jakarta.

Yunita, Nourma. 2013. "Analisis Efisiensi Penggunaan Modal Kerja ditinjau dari Rasio Aktivitas" Pada PT. Sarana Kencana Mulya di Samarinda. Jurnal Administrasi Bisnis. Fakultas IImu Sosial dan Politik. Universitas Mulawarman. Samarinda. 